This is an Accepted Manuscript of an article published by Regional \& Federal Studies, available online: http://dx.doi.org/10.1080/13597566.2014.911732

\title{
The 2013 South Tyrolean Election: The End of SVP Hegemony
}

\author{
Matthias Scantamburlo and Günther Pallaver \\ (University of Innsbruck)
}

\begin{abstract}
The results of the 2013 South Tyrolean elections, held on 27 of October, caused major changes in the political system of the autonomy. For the first time since the Second World War the South Tyrolean People's Party (SVP) lost its absolute majority. While the German secessionist parties increased their electoral support, the Italian parties suffered heavy electoral losses, thus leading to an underrepresentation of Italianspeakers in the political institutions. The election report shows how the electoral results affect the South Tyrolean system of ethnic proportional representation, which is characterised by an increasing asymmetry.
\end{abstract}

Keywords: territorial politics, regional elections, regionalist parties, nationalism, South Tyrol 


\section{Introduction}

After the February parliamentary elections in Italy, there were South Tyrolean elections on 27 October 2013, which were accompanied by a number of uncertainties. The South Tyrolean People's Party (SVP) attracted the attention of the national and international spectators. The SVP has always mustered an absolute majority in South Tyrolean state legislature elections since 1948, however, it has lost support over the last couple of years. It remained to be seen whether the SVP would be able to retain its absolute majority as a minority party, whether the German-speaking secessionist parties would increase their voter shares, whether the Italian parties continued to have a decreasing share of seats in the South Tyrolean legislature and whether the consociational model of democracy would be able to resist the centrifugal tendencies. The logic of the consociational model of democracy faced increasing pressure after the South Tyrolean autonomy, as a starting point for the latter model, was increasingly challenged by more and more German and Italian parties.

The first chapter of this election report outlines the political context in which the South Tyrolean elections occurred. The second chapter presents the various parties' election campaigns to be followed by an election result analysis in order to focus on the impact of the elections in the last chapter.

\section{Political Context}

South Tyrol (Südtirol in German and Alto Adige in Italian) is the northernmost province of Italy, and together with the neighbouring province of Trentino, it forms the autonomous region Trentino-Alto Adige/South Tyrol. Autonomy and group rights for the German- and Ladinspeaking minorities in South Tyrol were negotiated between Italy and Austria in the Gruber-De Gasperi Agreement of 1946. The unsatisfactory implementation of the agreement by the Italian state led to terrorist bombings, an intervention of Austria as 'protecting power' and the attention of the United Nations in the 1960s. The further negotiations culminated in the adoption of the 
Second Autonomy Statute (ASt) in 1972. Transferring nearly all important legislative and administrative powers from the region to the province until 1992, where the conflict was finally settled, the ASt empowered South Tyrol with an outstanding autonomy in economic, cultural and social matters. Nowadays South Tyrol is considered an ideal model of conflict resolution through territorial autonomy (Pallaver 2003, 273) and with a GDP of $€ 37,316$, it is the richest Italian province and one of the 25 wealthiest regions of Europe.

Along with Sicily, Sardinia, Aosta and Friaul Julian Venetia, the Trentino-South Tyrol region forms one of the five regions with a special statute in Italy. These regions were further strengthened by the constitutional reform of 2001, which paved the way for the federalisation of Italy. While the SVP - except for the 2013 elections always being the only party representing the German minority in the Italian parliament - never played a relevant role in the First Republic as a result of a miniscule number of seats in parliament, it again and again successfully tapped its potential as a possible coalition partner in the Second Republic due to a change of the electoral system. The SVP conventionally enters into electoral-coalition consultations with centre-left parties and centre-left governments, but has always abstained from joining a governing coalition in Rome. This is due to the fact that the SVP conceives itself as a party which represents the interests of the German and Ladin minority in South Tyrol only, but not those of the Italian state overall.

The political system of South Tyrol corresponds to Arend Lijphard's model of consociational democracy (Pallaver, 2008). As this model lessens political competitiveness and emphasises cooperation among groups, the distribution of political power in South Tyrol only partly mirrors the results of elections. The political process is rather characterised by mechanisms of power sharing that regulate competition between the relevant ethnic groupings. As a basic element of the ASt, the proportional representation of all language groups in political bodies is achieved through a proportional electoral system and the so-called 'ethnic quota 
system'. The latter furthermore establishes that all posts in the public sector as well as public funds are distributed according to language group percentages resulting from the last census (represented in Table 1). The principle of inclusion secures the participation of all relevant language groups at the governmental level and corresponding sub-systems. Therefore the provincial government in South Tyrol has to be composed according to the size of the language groups represented in the provincial assembly that has 35 members.

[Table 1 about here]

The consociational democracy model for the elites is strongly related to the ethnic division of South Tyrolean society. In this respect, the South Tyrolean party system is characterised by a deep ethnic cleavage that divides the electoral market into two ethnically distinct sub-arenas, so that German-speaking and Italian-speaking parties do not compete with each other.

In the German intra-ethnic arena, party competition is characterised by processes of 'ethnic outbidding' (Rabushka and Shepsle, 1972) between the moderate autonomist SVP, the populist right-wing liberals, Die Freiheitlichen $(\mathrm{dF})$, the nationalist-irredentist Südtiroler Freiheit (STF) and the Bürger Union (BU) that all can be considered separatist or irredentist parties. The Italian intra-ethnic arena instead always reflected the national party system. The implosion of the Italian party system in 1992-1993 and the end of the 'first republic' also affected the Italian parties in South Tyrol, which partly disappeared (as the Democrazia Cristiana (DC) or the Partito Socialista Italiano (PSI)) and were replaced by new ones (as the Partito Democratico (PD), the Popolo della Libertà (PdL) and the Lega Nord (LN)) following the logic of the 'second republics" imperfect bipolarism. Only the Green Party and its predecessors since 1978 organised themselves interethnically. 
The SVP, which sees itself as 'the ethnic catch-all party for all German- and Ladinspeaking South Tyroleans' (SVP, 1993), has been the hegemonic party in South Tyrol gaining the absolute majority since the first post-war election in 1948, thus governing the country for more than 60 years (Pallaver, 2011). Although with a percentage of 48.1, the majority of seats could be saved, the 2008 autonomous elections saw the SVP start the $14^{\text {th }}$ legislation period with the historical loss of the absolute majority of votes. Unpopularity reached its peak when the worst scandal in the post-war history of South Tyrol, at the centre of which lies the local energy company SEL (SEL scandal), touched the provincial government and the SVP leadership. ${ }^{1}$ Soon after the emergence of the scandal, the Landeshauptmann (governor), Luis Durnwalder, who also has been held politically responsible, officially stepped down after the legislative term ended, having ruled South Tyrol for 25 years (since 1989). His successor for the 2013 elections became the top candidate after intra-party primaries.

\section{Election Campaign}

Not only the SEL scandal, which after 60 years of incessant SVP government revealed the autonomy to be a deeply entrenched clientelistic system, but also the austerity measures imposed by the Italian government under Mario Monti, caused the German-speaking opposition to relaunch the discussion about the future constitutional status of South Tyrol, making secession an apparently valid argument. ${ }^{2}$

At the 2013 South Tyrolean elections, 4 German-speaking parties (SVP, dF, STF, BU), 9 Italian-speaking parties (PD, Forza Alto Adige-Lega Nord-Team Autonomie (TA), Movimento

\footnotetext{
${ }^{1}$ In 2012 the Italian public prosecutor's office proved that the province's energy sector assessor and the top managers of the SEL, distorted the results of tenders and thus awarded the company with contracts for the major hydroelectric plants in the province (Hinterwaldner 2013, 357).

${ }^{2}$ The Monti government repeatedly violated South Tyrol's constitutionally guaranteed financial autonomy amidst Italian austerity and consolidation efforts, so that the autonomous province of Bolzano/Bozen had to refer to the Italian constitutional court several times. This caused great political discontent vis-à-vis the central government and further strengthened the parties in South Tyrol which pursue the 'secession from Rome'.
} 
Cinque Stelle (M5S), L'Alto Adige nel cuore, Unitalia Movimento per l'Alto Adige, Scelta civica per l'Alto Adige-Südtirol, La Destra Minniti, Partito della Rifondazione Comunista, Partito dei Comunisti Italiani-Südtiroler Kommunisten) and one interethnic party (Greens) participated. The most significant lists and their issues are discussed in the following paragraphs.

\section{German Parties}

Südtiroler Volkspartei (SVP). The election campaign of the strongest South Tyrolean party was not only characterised by a leadership change but also by a (soft) change of party goals. After the complete implementation of the ASt in 1992 (final conflict settlement), the SVP goals on the centre-periphery dimension can more or less be described with the notion of 'dynamic autonomy' (SVP, 1993). After having achieved its objects with one of the most successful autonomies, this policy goal referred to the gradual extension of the autonomy and its adjustment to the socio-political and economic developments. This position was maintained during the 2008 election (SVP, 2008). In 2013, however, the SVP's positions changed with the goal of 'full autonomy' (Vollautonomie). Claiming full fiscal rights and a complete cultural autonomy (e.g. in education) from the Italian state as well as the possibility of concluding international agreements (SVP, 2013), marks a further step on the centre-periphery dimension. In comparison to 2008, strong emphasis was also given to the European dimension. The SVP has always been a Europhile party supporting the Idea of a Europe of the Regions, because of the re-approximation to the historical homeland of Tyrol. The strong emphasis can be explained by the legal implementation of the Euroregion Tyrol-South Tyrol-Trentino to a European Grouping for Territorial Cooperation (EGTC) in 2011. ${ }^{3}$

\footnotetext{
${ }^{3}$ There has been a cooperation mainly based on private law between the Austrian federal state of Tyrol and the two autonomous provinces of South Tyrol and Trentino for years. In 2006 the EU provided a legal instrument for cross-border cooperation, the EGTC. What is special about is the fact that this cooperative regime is endowed with legal personality in order to promote economic, social and
} 
Die Freiheitlichen $(d F)$. As the main German-speaking opposition party since the elections of 2008 , the $\mathrm{dF}$ represented the biggest threat for the hegemony of the SVP. The party was founded in 1992 following the patterns of the Austrian Freedom Party (FPÖ) led by the populist politician Jörg Haider, who also encouraged the founding of the dF. Similar to the FPÖ, the party combines a right-wing populist and xenophobic ideology with separatist claims. In accord with their populist opposition, the $\mathrm{dF}$ started a campaign called 'breaking the system' criticising the hegemonic ruling style of the SVP. The campaign especially referred to the 'SEL scandal', the 'clientelistic' system established by the SVP and its supporters as well as the democratic deficit generated by a party ruling alone $(\mathrm{dF}, 2013)$. On the centre-periphery dimension, the $\mathrm{dF}$ supported the idea of the so called 'Free State of South Tyrol' (Freistaat Südtirol) that, based on the right of self-determination, should be gradually implemented in cooperation with the Italian-speaking population. With their traditional notion of 'the locals first' (Einheimische zuerst), the party kept its anti-immigrant positions (dF, 2013).

Süd-Tiroler Freiheit (STF). Under the strong leadership of Eva Klotz, the break-off party of the former irredentist South Tyrolean Union (Union für Südtirol, UfS) could establish itself as a main player in the secessionist and German-nationalist milieu after the 2008 autonomous elections. As an ethnic one-issue party, the South-Tyrolean Freedom's main goal is the secession of South Tyrol through the full application of the right of self-determination. The STF still does not accept the incorporation into the Italian state and, after the application of the selfdetermination right, the South Tyroleans should choose between a new state and the return to Austria. The claim for secession is justified especially by the fear of losing Tyrolean identity and culture that, according to the STF, cannot be preserved under the actual status of territorial autonomy. Most of the relevant issues beside secession, such as economy, environment or

territorial cohesion. The three political entities (Länder) signed a cooperation agreement in 2011 (see e.g. Engl, 2013). 
immigration are interpreted in ethnic terms (STF, 2013). Lately also the current economic situation of Italy constitutes a further argument for South Tyrol's secession.

\section{Italian Parties}

Partito Democratico (PD). The most important centre-left party and Italian coalition partner of the SVP clearly started its election campaign with the goal to regain office. In its governing project for the future, the reform of the ASt took a central place. Although being in favour of further decentralisation 'the defence, adjustment and enforcement of the autonomy not as an egoistic stronghold of privileges, but as efficient instrument of autonomous government' (PD, 2013) show the national character of the party. The devolution of powers to the province should contribute to a real federalism and the financial restructuring of the state. The PD sees the future of South Tyrol in a 'pluri-linguistic society' beyond ethnic tensions to be achieved through 'pluri-lingual' education. In combination with the reform of the autonomy, the PD put strong emphasis on welfare and labour, especially to investments in education and research. The autonomy should also be used as an instrument to spend less and to avoid further cuts on the welfare system.

Forza Alto Adige/Lega Nord/Team Autonomie (TA). After the dissolution of the Italian centre-right party PdL, this party list was created for the 2013 autonomous elections and, along with the 'civic list' of Team Autonomie, it also includes the Italian parties Lega Nord and Silvio Berlusconi's re-created Forza Italia. This coalition of parties sees the reform of the autonomy especially in favour of the Italian speaking population. An important claim in the platform is the recognition of the plurilingual citizen's rights (i.e. people that grow up in plurilingual families and are not either German or Italian speaking) that until now are not stated in the ASt (TA, 2013). Strong emphasis on home and family, economic questions as well as regulations on immigration clearly show that parties as the LN and FI are part of the coalition. 


\section{Interethnic Parties}

Verdi/Grüne/Verc/SEL (The Greens). The only interethnic Party in South Tyrol unified itself with the Italian leftist party, Sinistra Ecologia Libertà (SEL), continuing the successful coalition of the national elections, which managed to delegate the first German-speaking candidate to the Italian parliament (February 2014) outside the rows of the SVP. In the platform, partly written in German and partly in Italian, the party criticises the separation of ethnic groups as antiEuropean and non-democratic and condemns the rise of nationalism and separatism. Concerning the autonomy for the Greens, the most important issue is its democratisation from the bottom especially through the strengthening and further implementation of mechanisms of direct democracy and equal opportunities. The coming legislative term should be used to create the 'third autonomy' through a constituent process of citizen's participation (Verdi/Grüne/Verc/SEL, 2013). Especially this issue shows their reformist character towards the actual ASt. The classical values of a Green party are illustrated in the further emphasis on social justice, green economy and multiculturalism.

\section{Election results and Discussion}

The results of the South Tyrolean elections (represented in Table 2) have confirmed three trends, which have already become visible over the last couple of years. The SVP loses its absolute majority, the German-speaking secessionist parties are on the rise, while an increasingly smaller number of Italian parties move into the state legislature, the Landtag.

Obtaining $45.7 \%$ and thus losing $2.4 \%$, the SVP only gained 17 out of 35 seats, with this respectable result mainly being owed to the top candidate, Arno Kompatscher. The Germanspeaking secessionist and oftentimes right-wing populist parties (dF, STF, BU) mustered close to $6 \%$ more, thus winning two additional seats. The two Italian national parties, the PD and the M5S, remained below expectations and scored worse than in the parliamentary elections of February 2013. Forza Italia and Lega Nord ran for the elections together with the 'civic list' 
Team Autonomy. After the elections, the only female deputy left this electoral alliance in order to form a separate autonomy-seeking faction in the state legislature. The attempt by Scelta Civica to become the governing partner of the SVP as a nation-wide but still autonomy-seeking party of the centre has miserably failed. The strong decrease in the election turnout of Italians has resulted in the fact that there were only 5 Italian-speaking deputies in the 35-seats-strong state legislature in 2013, while there were only 8 in 2008.

The new governing coalition consists of 17 deputies of the SVP and two of the PD. Thus, we are dealing with the continuation of the old but weaker and smaller coalition, which mainly focuses on job creation programs and the reform of the ASt (Koalitionsabkommen 2013).

\section{No more absolute majority for the SVP}

For the first time in post-war South Tyrol, the SVP lost its absolute majority. Overall the main reasons can be found in the gradual dissolution of traditional electoral and social milieus (see e.g. Arzheimer, 2006). But there are also specifically regional reasons, such as the overall European developments. By securing the ASt and adequate minority protection, the traditional 'fetishism of unity' of South Tyroleans is gradually eroding - an ideology which prioritised the ethnic unity of the German- and Ladin-speaking minorities above all other social tensions in order to achieve autonomy and full minority rights. When these goals were finally achieved in 1993, the bond based on ethnic commonalities also started to weaken. The unbroken power of the SVP also caused clientelistic conditions which ultimately led to political scandals and abuse. The SVP's claim to be the catch-all party for all German and Ladin speakers thus came to an end. Until the turn of the millennium, the SVP always mustered around $80 \%$ of the Germanand Ladin-speaking vote, whereas, in 2013, this figure dropped to approximately $54 \%$.

The loss of the absolute majority also had an impact on the formation of coalitions. The SVP always had to govern with Italian coalition partners despite of an absolute majority, as prescribed by the ASt. The negotiations to form a coalition after the 2013 elections showed for 
the first time that an Italian party does not just join a coalition with the SVP for ethnic but also for political reasons.

The loss of the absolute majority has also put into question the claim to represent the German and Ladin speakers alone vis-à-vis Rome and Vienna. In the past, it was just the SVP which negotiated autonomy and minority protection safeguards with Rome and the Viennese protective power. This claim to be the sole representative of the minority is ever more difficult to legitimise.

\section{The rise of secessionist parties}

In the 1973 South Tyrolean elections, one year after the autonomy statute came into force, there was only one anti-autonomy party in the South Tyrolean legislature, the neo-fascist Movimiento Sociale Italiano (MSI, 4\%), whereas all other parties constituted autonomy parties. Autonomy parties are parties which, according to the typology by De Winter (1998), fight for the autonomy of their respective regions, anti-autonomy parties, in turn, overtly reject autonomy.

Semi-autonomy parties are those parties which are affirmative of autonomy but prefer the latter just as a starting point for ultimate secession (for Italian parties, in turn, this means a reinforced claim for the return of the Italian state). As can be seen in Table 3 there were no such parties in 1973.

This picture changed in the 2013 South Tyrolean elections. The autonomy parties (SVP, PD, Greens, Movimiento 5 Stelle, Team Autonomie, Alto Adige nel Cuore) mustering a total $68.2 \%$ of the vote are confronted with the anti- and semi-autonomy parties that account for 27\%. A quarter of South Tyrolean voters elected a secessionist party.

As far as the evolution of the ideological poles is concerned, one can clearly notice the erosion of the extreme left and right poles along the political spectrum over the last 40 years. The centre-parties have also suffered heavy losses, which have also dropped from 25 (1973) seats to 17 in 2013. The centre-right parties, in turn, have gained electoral support, from no 
mandate at all in 1973 to 12 seats in 2013. In contrast to Sartori's (1976) ideological distance parameter, we prefer to use the distance of parties to autonomy when measuring the polarity to categorise the South Tyrolean party system. The political centre is formed by the autonomy parties, whereas the anti-autonomy parties constitute anti-system parties. Since there are only German anti- and semi-autonomous parties, we may well speak of a moderate autonomy party system after the 2013 elections, paraphrasing Sartori.

The contrast between centre and centre-left parties/pro-autonomy and centre or centre-right parties/anti- or semi-autonomy reflects the entire history of the South Tyrolean autonomy. It shall be noted that it is the anti- and semi-autonomy parties are all part of the German camp today, whereas these parties were found in the Italian camp in the past.

\section{Consociational Democracy}

The autonomy model established in 1948 corresponds to the consociational democracy typology (see Lijphard, 2004: 96-109), and it defines the spheres of influence of the various language groups (see Pallaver, 2011: 303-327). Among other things, this model includes the power share of all relevant linguistic groups in the government and in the remaining subsystems. The principle applied here is that of the proportional inclusion of all language groups.

This principle has gotten strongly out balance over the last 20 years. According to the ASt, the language groups have to be represented as well in the South Tyrolean government in accordance with their proportional strengths in the South Tyrolean legislature. In the First Republic the traditional governing partners of the SVP, the DC and the Socialists (PSI), always represented the majority of Italian speakers. With the elections of 2013, the number of Italian deputies plummeted to five, which equals only one representative in the South Tyrolean government. This means that the Italian party only represented $30 \%$ of the Italian population. The same trend is visible at the communal level (Goller, 2013). The ever decreasing inclusion 
of the Italian speakers is, among other things, one reason for 'Italian discomfort', because the Italians do not feel they are represented in the main decision-making bodies, thus leading to a gradual decrease in political influence. This causes a problem in the system overall because the principle of maximum inclusion of all linguistic groups in the South Tyrolean government does not materialise anymore.

\section{Conclusion}

It is well possible that the 2013 elections paved the way for the future, because according to the coalition agreement, a reform convention is to readapt the autonomy statute to the new needs of a multilingual community. It is thus necessary to strengthen the consociational model of democracy in order for the Italian speakers to be better represented in the politico-cultural institutions, especially in the South Tyrolean legislature and the executive branches at communal level. The secessionist parties have not just gained electoral support as a result of the SVP crisis, but also because of the Italian economic situation. The support for the latter increasingly forces the SVP to respond by claiming 'full autonomy'. It remains to be seen whether this is a viable und useful strategy. 


\section{References}

Astat (2013), Statistisches Jahrbuch für Südtirol. Bozen. http://www.provinz.bz.it/astat/download/JB2013_K3.pdf (27.1.2014).

Arzheimer, K. (2006), 'Dead Men Walking? Party Identification in Germany, 1977-2002', Electoral Studies 25, pp. 791-807.

De Winter, L. and Türsan H. (eds) (1998), Regionalist Parties in Western Europe. London/New York: Routledge.

dF (2013), Wahlprogramm der Freiheitlichen für die Landtagswahl 2013. Die Freiheitlichen.

Engl, A. (2013), 'Ein Instrument zwischen Gemeinschaftspolitik und nationalem Recht: Die Durchführung der Verordnung über den Europäischen Verbund für Territoriale Zusammenarbeit in ausgewählten EU-Mitgliedsländern', in Europarecht 3, pp. 285-306.

Ergebnisse der Landtagswahlen 2013. http://www.landtagbz.org/de/wahlen/ergebnisselandtags wahlen.asp (28.1.2014).

Goller, M. (2013), 'Die Vertretung der italiensichen Sprachgruppe in den Südtiroler Gemeinden 1952-2010', in Pallaver G. (ed), Politika13. Jahrbuch für Politik/Annuario di politica/Anuar de politica (Südtiroler Gesellchaft für Politikwissenschaft/Società di Scienza Politica dell'Alto Adige/Sozietà de scienza pulitica de Sudtirol). Bozen: Edition Raetia, pp. 283-302.

Hinterwaldner, K. (2013), 'Ein System zerbricht', in Pallaver G. (ed), Politika13. Jahrbuch für Politik/Annuario di politica/Anuar de politica (Südtiroler Gesellschaft für Politikwissenschaft/Società di Scienza Politica dell'Alto Adige/Sozietà de scienza pulitica de Sudtirol). Bozen: Edition Raetia, pp. 345-357.

Koalitionsabkommen zur Bildung der Landesregierung für die Legislaturperiode 2013 bis 2018. http://www.provinz.bz.it/land/landesregierung/download/koalitionsabkommende_2013-12-30.pdf (28.1.2014).

Lijphart, A. (1977), Democracy in Plural Societies. A Comparative Exploration. New Haven/London: Yale University Press.

Pallaver, G. (2003), 'Democrazia consociativa in Alto Adige. Regolamentazione dei conflitti etnici tra disciplina giuridica e trasformazioni sociali', in Di Michele A./Palermo F./Pallaver G. (eds), 1992. Fine di un conflitto. Dieci anni dalla chiusura della questione sudtirolese, Bologna: Il Mulino, pp. 273-317.

Pallaver, G. (2008), 'South Tyrol's Consociational Democracy: Between Political Claim and Social Reality', in Woelk J., Palermo F. and Marko J. (eds), Tolerance trough Law: Self Governance and Group Rights in South Tyrol. Leiden/Boston: Martinus Nijhoff Publishers, pp. 303-327.

Pallaver, G. (2011), 'The Südtiroler Volkspartei', in Elias A. and Tronconi F. (eds), From Protest to Power. Autonomist parties and the challenges of representation. Wien: Braumüller, pp. 171-193.

PD (2013), La Trasformazione dell'Autonomia e la Sfida dell'Autogoverno. Partito Democratico.

http://www.partitodemocratico.bz/index.php/it/component/docman/doc_view/88920130529-documento-politico (8.1.2014). 
Rabushka, A. and Shepsle, K. (1972), Politics in Plural Societies: A Theory of Democratic Instability. Columbus, Ohio: Charles E. Merrill.

Sartori, G. (1976), Parties and party systems. A Framework for analysis. Cambridge: Cambridge Univ. Press.

STF (2013), Wahlprogramm der Süd-Tiroler Freiheit 2013. Süd-Tiroler Freiheit. http://www.suedtiroler-freiheit.com/wahlprogramm-der-sued-tiroler-freiheit-2013/ (8.1.2014).

SVP (1993), Das neue Programm der Südtiroler Volkspartei. Beschlossen von der Landesversammlung am 8. Mai 1993. Südtiroler Volkspartei. http://www.svp.eu/smartedit /documents/presse downloads/grundsatzprogramm.pdf (8.1.2014).

SVP (2008), Mit Euch für Südtirol. Wahlprogramm 2008-2013. Südtiroler Volkspartei. http://www.svp.eu/smartedit/documents/presse_downloads/svp-wahlprogramm-20082013.pdf (8.1.2014).

SVP (2013), Südtirol! Gutes Bewahren. Neues Wagen. Das Programm der Südtiroler Volkspartei Landtagswahl 2013. Südtiroler Volkspartei. http://landtagswahl.svp.eu/positionen/ (8.1.2014).

TA (2013), Programm/a. Team Autonomie. http://www.teamautonomie.org/programma-3 (18.1.2014).

VERDI/GRÜNE/VERC/SEL (2013), Sauberes Land - Gesunde Politik. Die grünen Vorschläge für ein neues Südtirol. Verdi/Grüne/Verc/SEL. http://www.verdi.bz.it/wpcontent/uploads 12013/09/130918ProgrammA_VerdiGrueneVerc.pdf (3.1.2014). 


\section{Tables}

Table 1. Population development in South Tyrol (1900-2011) according to language groups (\%)

\begin{tabular}{|c|c|c|c|}
\hline Year & German & Italian & Ladin \\
\hline 1900 & 88.8 & 4.0 & 4.0 \\
\hline 1910 & 89.0 & 2.9 & 3.8 \\
\hline 1921 & 75.9 & 10.6 & 3.9 \\
\hline 1961 & 62.2 & 34.3 & 3.4 \\
\hline 1971 & 62.9 & 33.3 & 3.7 \\
\hline 1981 & 64.9 & 28.7 & 4.1 \\
\hline 1991 & 67.9 & 27.6 & 4.3 \\
\hline 2001 & 69.1 & 26.4 & 4.3 \\
\hline 2011 & 69.4 & 26.0 & 4.5 \\
\hline
\end{tabular}

Source: Astat (2013) 
Table 2. Election Results 2013

\begin{tabular}{|c|c|c|c|c|c|c|}
\hline \multicolumn{2}{|r|}{ Party } & Votes & $\%$ & $+/-$ & Seats & $+/-$ \\
\hline 政, & $\begin{array}{l}\text { SVP } \\
\text { South Tyrolean People's Party }\end{array}$ & 131.255 & 45.7 & -2.4 & 17 & -1 \\
\hline & $\begin{array}{l}\mathrm{dF} \\
\text { Freedom Party }\end{array}$ & 51.510 & 17.9 & +3.6 & 6 & +1 \\
\hline & $\begin{array}{l}\text { Verdi-Grüne-Verc - SEL } \\
\text { Green Party - Left Ecology Freedom }\end{array}$ & 25.070 & 8.7 & +2.9 & 3 & +1 \\
\hline 隹 & $\begin{array}{l}\text { SF } \\
\text { South-Tyrolean Freedom }\end{array}$ & 20.743 & 7.2 & +2.3 & 3 & +1 \\
\hline P.) & $\begin{array}{l}\text { PD } \\
\text { Democratic Party }\end{array}$ & 19.210 & 6.7 & +0.7 & 2 & $=$ \\
\hline (min & $\begin{array}{l}\text { Forza Alto Adige - Lega Nord - Team } \\
\text { Autonomie } \\
\text { Forza Alto Adige - Northern League - Team } \\
\text { Autonomy }\end{array}$ & 7.120 & 2.5 & -5.8 & 1 & -2 \\
\hline 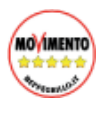 & $\begin{array}{l}\text { M5S } \\
5 \text { Stars Movement }\end{array}$ & 7.100 & 2.5 & +2.5 & 1 & +1 \\
\hline 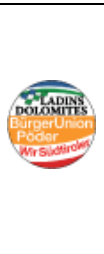 & $\begin{array}{l}\text { BürgerUnion - Ladins Dolomites - Wir } \\
\text { Südtiroler } \\
\text { Citizens Union - Ladins Party - We South } \\
\text { Tyroleans }\end{array}$ & 6.065 & 2.1 & -0.2 & 1 & $=$ \\
\hline (4) & $\begin{array}{l}\text { L'Alto Adige nel Cuore } \\
\text { Alto Adige in the Heart }\end{array}$ & 6.061 & 2.1 & -6.2 & 1 & -2 \\
\hline Voter & nout & 289.844 & 77.7 & -2.4 & & \\
\hline
\end{tabular}

Source: Ergebnisse der Landtagswahlen 2013 (2013) 
Table 3. Positions of parties concerning autonomy 1973-2013

\begin{tabular}{|c|c|c|c|c|c|c|c|}
\hline & \multicolumn{3}{|c|}{ Italian Parties } & Interethnic & \multicolumn{3}{|c|}{ German Parties } \\
\hline Year & $\begin{array}{c}\text { Anti- } \\
\text { Autonomy } \\
\text { Parties }\end{array}$ & $\begin{array}{c}\text { Semi- } \\
\text { Autonomy } \\
\text { Parties }\end{array}$ & \multicolumn{3}{|c|}{ Autonomy Parties } & $\begin{array}{c}\text { Semi- } \\
\text { Autonomy } \\
\text { Parties }\end{array}$ & $\begin{array}{c}\text { Anti- } \\
\text { Autonomy } \\
\text { Parties }\end{array}$ \\
\hline 1973 & $\begin{array}{c}\text { MSI-DN } \\
4.0 \%\end{array}$ & - & $\begin{array}{c}\text { DC, PCI, } \\
\text { PSI, PSDI } \\
28.9 \%\end{array}$ & - & $\begin{array}{c}\text { SVP, SPS, } \\
\text { SFP } \\
63.3 \%\end{array}$ & - & - \\
\hline \multicolumn{8}{|c|}{$\begin{array}{l}\text { Autonomy Parties: } 92,1 \% \\
\text { Semi-Autonomy Parties: - } \\
\text { Anti-Autonomy Parties: 4,0\% }\end{array}$} \\
\hline 2013 & - & - & $\begin{array}{c}\text { PD, AA nel } \\
\text { Cuore, } \\
\text { M5S,Team } \\
\text { Autonomie } \\
13.8 \%\end{array}$ & $\begin{array}{c}\text { Grüne } \\
8.7 \%\end{array}$ & $\begin{array}{c}\text { SVP } \\
45.7 \%\end{array}$ & $\begin{array}{l}\mathrm{dF}, \mathrm{BU}- \\
\text { Ladins } \\
\text { Dolomites } \\
20 \%\end{array}$ & $\begin{array}{c}\text { STF } \\
7.2 \%\end{array}$ \\
\hline $\begin{array}{l}\text { Diffe- } \\
\text { rence }\end{array}$ & $-4.0 \%$ & - & $-15.1 \%$ & $+8.7 \%$ & $-17.6 \%$ & $+20 \%$ & $+7.2 \%$ \\
\hline \multicolumn{8}{|c|}{ Autonomy Parties: $68.2 \%$} \\
\hline
\end{tabular}

Source: Own calculations according to the 1973 and 2013 South Tyrolean elections. Parties which did not manage to move into Parliament are not included. That is why the percentages do not amount to $100 \%$.

Abbreviations: DC: Democrazia Cristiana; dF: Die Freiheitlichen; LN: Lega Nord; MSI-DN: Movimento Sociale Italiano-Destra Nazionale, PCI: Partito Comunista Italiano; PD: Partito Democratico; PSDI: Partito Socialdemocratico Italiano; PSI: Partito Socialista Italiano, STF: Süd Tiroler Freiheit; UfS/BU: Union für Südtirol/Bürgerunion; BU/L/W: BürgerUnion-Ladins DolomitesWir Südtiroler; AA nel Cuore: Alto Adige nel Cuore. 